\title{
Service Quality, Customer Satisfaction and Loyalty: An Empirical Analysis of Banking Sector in Pakistan
}

\author{
Mohsin Zafar ${ }^{1}$, Sana Zafar ${ }^{2},{ }^{*}$ Aasia Asif ${ }^{3}$, Ahmed Imran Hunjra ${ }^{1}$, H. Mushtaq Ahmad ${ }^{4}$ \\ ${ }^{1}$ Iqra University Islamabad, Pakistan \\ ${ }^{2}$ NUST Business School Islamabad, Pakistan \\ ${ }^{3}$ Shaheed Zulfiqar Ali Bhutto Institute of Science and Technology, Islamabad, Pakistan \\ ${ }^{4}$ Bahria University Islamabad, Pakistan \\ *aasia18@gmail.com
}

\begin{abstract}
The basic aim of this study is to explore most common constructs for quality of banking services, which influence customer satisfaction and examine the impact of customer satisfaction on customer loyalty in the context of banking relationships. The questionnaire was used to collect the data from 192 valid respondents by convenience sampling method. SPSS was used to analyze the data and AMOS was used to test the model. The results of the study show that there is a positive and significant link between customer satisfaction and constructs of service quality like tangibility, reliability, competence conflict handling and further study inferred that customer satisfaction is positively significant related to customer loyalty.
\end{abstract}

Key words: Customer Satisfaction, Service Quality in banking, Customer Loyalty.

\section{Introduction}

In this era of increasing competition, researchers and practitioners alike have realized the importance of achieving high levels of customer satisfaction. Especially in the case of service sector where many companies, in order to drive high levels of customer satisfactions are focusing upon service quality improvement issues. Service sector has revolutionized greatly in 90 s under the burden of current marketing environment. One of the biggest reasons of this development is competition, which is opposing geographical, industrial, and regulatory limitations, producing new outputs, utilities, market fair chances, and creating additional knowledge and systems-oriented business and management operations (Liao \& Cheung, 2002). The banking industry provides numerous services to their clients. Prior studies have discussed the relationship of quality and services with customer satisfaction (Zeithaml et al., 2002; Yang \& Fang, 2004). Past research focuses on the affinity between service quality and customer satisfaction (Bitner et al., 1990; Parasuraman et al., 1988). Part of measurement SERVQUAL is widely used, and applicable to banking industry (Yavas et al., 1997). It is widely accepted that service quality, customer value and satisfaction are the most important sources of gaining competitive advantage for manufacturing and service organizations (Zeithaml et al. 1996; Bolton \& Drew, 1991; Parasuraman et al., 1988, 1991). These success factors are prioritized by managers in this customer-centered era (Zeithaml, 1988). However, conclusions have been made regarding service quality, customer satisfaction and related studies are rather classified. It has been suggested to gain the competitive advantage; firms should make use of firm-customer relationships to extract information (Ndubisi et al., 2009). The relationship-marketing concept emerged in the nineteenth century and is still popular among marketing scholars and practitioners until today.

Financial sector has also been subject to the same paradigm. In banking industry, the up-growth in IT has had a mammoth outcome by bringing customer friendly banking utilities. Most of the electronic transactions systems are new, also with advanced technologies in financial academies are bringing enhanced banking experience. This invention provides banks and DFIs substitute freighting approaches to provide banking products and services to clients more easily and economically without reducing the current standards. Besides understanding customers, it also helps to increase profit as well as reduce cost. Research has shown that the cost of retaining one loyal customer is pretty less than that of a new customer. The rationale behind this study is that it explores the service quality of the most efficient / contributor sector to the economy. What 
kinds of services are being delivered to the customers and how much customers are satisfied towards the services provided by this sector. This study aims to explore most common constructs for quality of banking services and to understand the factors that influence customer satisfaction in banking sector. It also manipulates the effect of customer satisfaction on loyalty in banking relationships and to discuss the come up with recommendations that may help banks to increase customers' satisfaction and loyalty. The rest of this paper is organized as follows: Section II discusses review of available literature and section III is about the methodology. Empirical results and discussions of the study are explained in section IV. Finally, conclusions, limitations and future research are drawn in section $\mathrm{V}$.

\section{Literature Review}

Customer satisfaction has widely been addressed in literature; defined satisfaction as a post choice evaluative judgment concerning a specific purchase decision (Oliver, 1980). In the marketing literature, customer Satisfaction is one of the very important outcomes. It serves to link processes culminating purchase and consumption with post purchase phenomena such as repeat purchase, brand loyalty and attitude change (Surprenant and Churchill, 1982). This definition is supported by and Mishra (2009). Most of the researchers agree that satisfaction is an evaluation or attitude that is formed by the comparison made by customer for their pre-purchase expectations of what they would receive from the product to their subjective perception of the performance they actually did receive (Oliver, 1980). A basic point of interest in many banking studies have been asked how satisfaction is formed? Studying in business literature (Oliver 1980; Churchill \& Surprenant, 1982) as well as McKinney et al., (2002). The theory of disconfirmation is considered as the base of satisfaction models. According to this theory, difference between the expected and experienced standards determined the satisfaction (Khalifa \& Liu, 2003). Customer expectation can be defined as expectation of a customer regarding a product (Mckinney et al., 2002). Perceived performance or expectation is defined as a customer's belief related to the performance of a product (Cadotte et al., 1987). Perceived quality is a perception about the differentiation of a product (Parasuraman et al., 1988). Disconfirmation is defined as the limit to which a product fails to meet a customer's expectation (Mckinney et al., 2002; Spreng et al., 1996).

In a competitive market place, understanding customer's needs is very valuable. Therefore, companies are preferring customers over products nowadays. Satisfaction is the main source of attracting customers (Patterson et al., 1997). Customer loyalty has become a great challenge for companies in the current era (Khalifa \& Liu, 2003). In banking sector, it is very important to understand the factors leading to satisfaction, which will evidently lead to loyalty (Vanriel et al., 2001). The competition is increasing day-by-day regarding services in banking sector. It has been observed that Information Technology is replacing the human labor at a rapid rate (Jun \& Cai, 2001). It has been proved that organizations need to give more consideration towards customer satisfaction (Parasuraman \& Grewal, 2000). Mols (2000) argued that the home-based Internet banking might lead to strong relationships with customers because customer expectations have a tendency to change over time. In the same manner, service quality is another important issue while gaining customer satisfaction. Maintaining service quality is extremely necessary in current and highly competitive banking sector (Mefford, 1993). For this, bankers need to identify the attributes affecting customer satisfaction. Literature gives very limited information related to these attributes (Jun \& Cai, 2001). More research should be conducted to know about the attributes leading to customer satisfaction (Parasurman et al., 1991). Service quality has a great impact on firm's performance. Between academics customer satisfaction and service quality is considered as a distinct feature and bears great importance (Oliver, 1980). Most experts agree that customer satisfaction is a short-term measurement tool where as service quality is a long-term tool (Howcroft et al., 2002). Service quality is determined by the comparison made by the customers between their expectations and experiences (Gurau, 2002; Parasuraman et al., 1988).

Service quality is also linked with customer loyalty. While some researchers are in the view that customer, satisfaction rather than service quality exerts stronger influences on buying intentions of the customers (Cronin and Taylor, 1992). Some other researchers also provided the strong empirical evidences supporting the fact that service quality increases the customer intentions to remain with any company. For example, Buzzell and Gale (1987) found out that service quality results in increased market share and repeated sales that ultimately leads to customer loyalty. Zeithaml et al. (1996) also concluded in their research that when 
organizations improve the quality of their services, customers' unfavorable intentions are decreased while favorable behavioral intentions are increased. Traditional service systems are still demanded by the customers along with the internet-based banking (Yang and Fang, 2004). Numerous studies have been carried out to identify the attributes which contribute in the up-lift of service quality (Parasuraman et al., 1988; Pitt et al., 1999). Competence as a key relationship-marketing variable is supported by the rationale that people tend to value and nurture relationships with competent individuals. Such competence may be the result of technical, intellectual, social and commercial skills. The organizational behavior researches recognizes the existence of expert power influencing others by possessing knowledge or skills that the others value (McShane \& Travaglione, 2007; Drucker, 2001). Conflict handling refers to the service provider's capability to reduce the obvious disagreements (Dwyer et al., 1987). The conflicts should be eliminated on time or else should be dealt with intelligence and should be discussed openly. Rusbult (1988) argued that a person's loyalty and future relationship with a firm depends on their past relationship with it while evaluating all the alternatives available. The competence of a bank to handle conflict will determine customer satisfaction and customer loyalty. In addition, Fen \& Lian (2007) established both customer satisfaction and service quality as predictors for re-patronage in restaurant industry moreover; they found customer satisfaction as a more suitable candidate for re-toleration. However, the same variable has yet been applied to banking industry further its presence has not been examined along other variables leading to customers' satisfaction.

Furthermore, in the service quality studies, dependability /reliability has also appeared as an operations element of prime importance ( Berry, 1995; Zeithaml et al., 1990; Heskett et al., 1994; Parasuraman, 1991; Stank et al. 1999; Patterson and Marks ,1992; Bloemer et al. 1999) all of these researchers have also identify a positive relationship between user satisfaction and perceived dependability. Earlier researches were solely dependent on the surveys carried out for customer satisfaction and service quality (Bolton, 1998) and enhanced their research for the factors affecting customer satisfaction (Churchill \& Surprenant, 1982; Swan \& Trawick, 1981; Bearden \& Teel, 1983). Studies have widely highlighted the relationship between customer satisfactions and customer loyalty (Rust \& Zahorik, 1993; Fornell, 1992; Patterson \& Spreng, 1997; Taylor \& Baker, 1994; Bearden \& Teel, 1983) emphasized on the importance of customer satisfaction, as it is a significant predictor of customer loyalty. Likewise, Rust \& Zahorik, (1993) declared that a contended customer exhibits greater retention and expressed significantly positive impact of customer satisfaction on customer loyalty. Particularly, customer satisfaction and repurchase intentions are inter-related (Rust \& Zahorik, 1993; Taylor \& Baker, 1994; Patterson \& Spreng, 1997; Bolton, 1998; Hellier et al., 2003 and Fen \& Lian, 2007). It is very important to identify the elements of service quality in order to gain customer satisfaction (Johnston, 1995). Angur et al. (1999) examined the applicability of alternative service quality measure in the Retail Banking industry in India. They conducted their research on the consumers of two major banks in India. They use SERVQUAL model to measure the overall service quality. They found that all the dimensions are not equally important in explaining variance in overall service quality. The result indicated that responsiveness and reliability seem to be the most important dimensions followed by the empathy and tangible dimensions; whereas, assurance appears to be the least important dimension. Finally, they concluded that SERVQUAL is the best measure of service quality in banking industry.

Hypotheses: The following hypotheses, for customer satisfaction and service quality in banking sector, have been developed from the literature review:

H1: Tangibility will result in customer satisfaction.

H2: Reliability will result in customer satisfaction.

H3: Competence will result in customer satisfaction.

H4: Conflict Handling will result in customer satisfaction.

H5: Customer Satisfaction will result in customer loyalty.

Theoretical Model: The researchers offered a conceptual model constructed based on literature review representing the relationship between customer satisfaction and service quality as: 


\section{Figure 1: Conceptual Model}

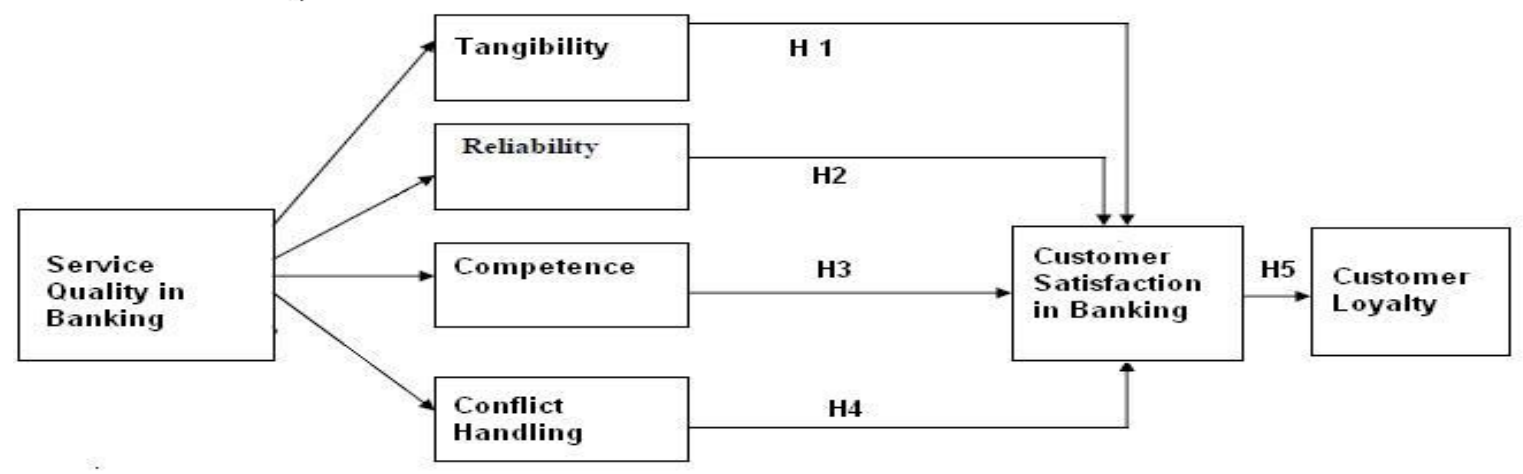

Conceptual Model for Study

\section{Methodology}

The questionnaire-based survey was conducted in different cities of Pakistan including Rawalpindi / Islamabad Lahore and Karachi. Total 500 questionnaires were distributed using convenience-sampling techniques and people had to fill them based on their banking experience. The response rate has been $38.4 \%$, which means that only one hundred \& ninety two properly filled survey forms were brought back to target respondents. Respondents were the customers of different banks from several cities of Pakistan. Questionnaire distribution turned out to be a tedious task due to time, resource and budget limitations. The questionnaire was demarcated into two sections; first section containing demographics related to usage of internet banking whereas second one measured the effects of service quality determinants upon customer satisfaction and loyalty. One questionnaire was handed out to each respondent while explaining the whole questionnaire in order to provide comfort to respondents in answering the questions. Initially a pilot study was conducted upon 58 respondents. The survey-based questionnaire was personally administered to establish the validity. The data was collected from customers in different banks who agreed to give time and help in pilot study data collection. Objectives of study and requirements were explained briefly and after pilot testing the instrument were finalized.

Measurement of the Constructs: Four service quality determinants have been chosen from the study carried out by (Zethaml et al., 2000; 2002). These elements are also accepted by other authors (Jun \& Cai, 2001; Yang \& Fang, 2004; Liu \& Arnett, 2000; Ndubisi et al., 2009) to conclude the service quality in banking sector. In the present study service quality was measured by four variables which were tangibility (four items), reliability having three items, competence was measured with four items and there were three items of conflict handling. Satisfaction and loyalty have three and four items, respectively, used in this study. The element used to calculate the reaction was 5-Point likert scale where 5 was the upper-most level of unity and 1 was the lower-most one. The SPSS technique was used for data analysis and findings and AMOS was used for model testing.

\section{Result and Discussion}

The objective of this study is to investigate the most preferred elements for service quality in banking sector, which effect customer satisfaction as well as analyze the effects of customer satisfaction on customer loyalty regarding banking relationships both theoretically and empirically. The results of current study show that maximum respondents are male $(86.5 \%)$ while only $13.5 \%$ are female participants and $88.5 \%$ respondents with age bracket of $30-40$ years. 
Table 1: Source of Measure

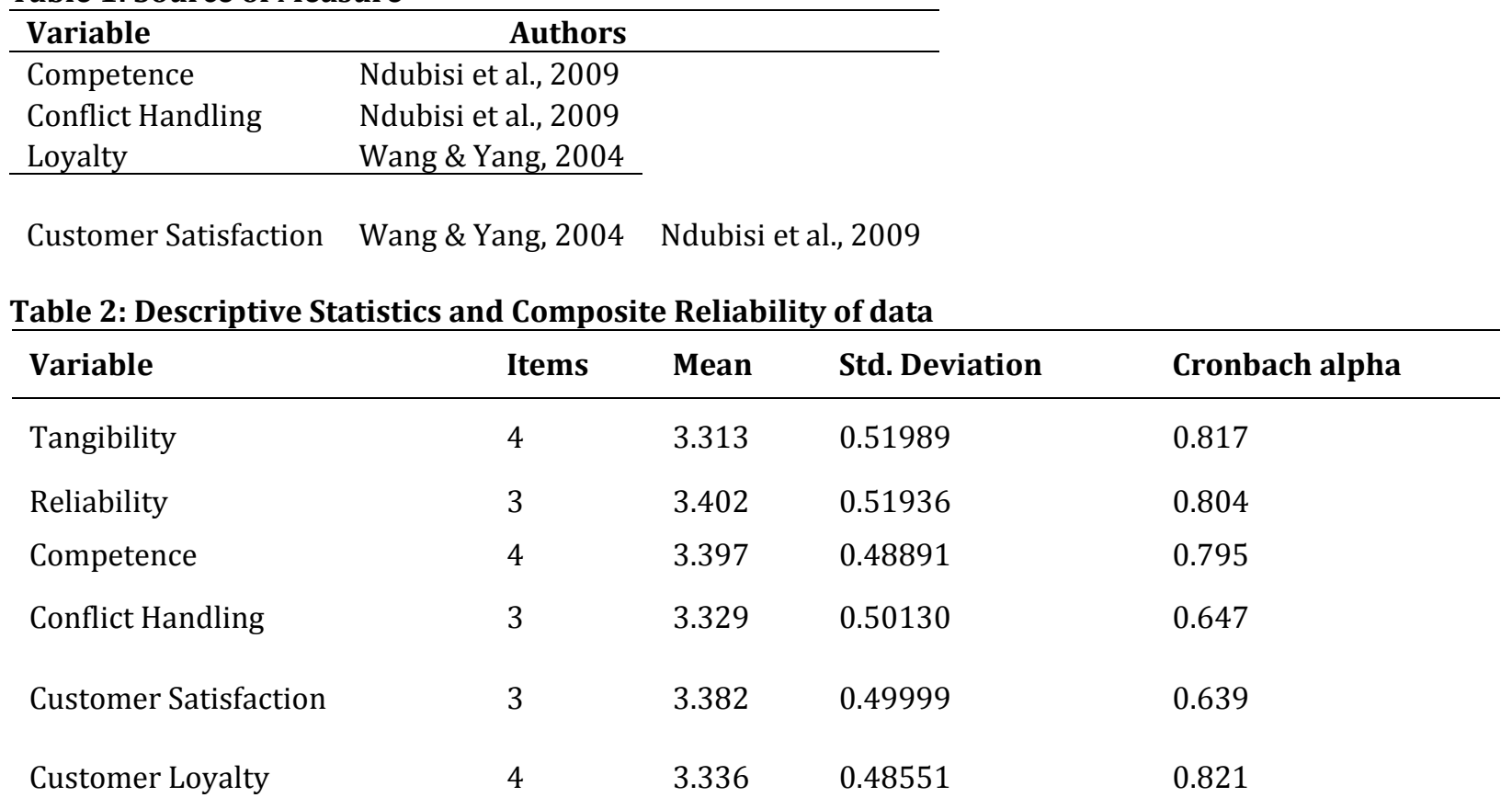

The descriptive statistic shows the direction of response, in the above table the mean value that is 3.313 of tangibility reveals respondents are agreed that tangibility enhance the service quality of banking as well as reliability, competence and conflict handing the mean value depicts the response rate of potential respondents is in positive side. Whereas, the mean value reveals customer satisfaction and loyalty are also responded agreed. The table further gives the information about reliability of data. Reliability shows the consistency of the outcomes. Inner appropriateness of the whole scale is the most widely and accepted measure of reliability. Coefficient alpha determines it and is also known as Cranach's alpha. In the context of reliability of data, the tangibility with reliability of 82 percent, reliability of ( 80 percent), the Cronbach Alpha of competence is 0.795 , the conflict handling variable has reliability 0.647 , customer satisfaction Cronbach Alpha value is 0.639 and the reliability of customer loyalty is 82 percent, whereas, the overall Cronbach Alpha is 0.886 .

The below model demonstrates the affinity among the variables and it helps to calculate the effects of service quality constructs and its relations to customer satisfaction in banking sector and the importance and role of each variable for customer satisfaction. It also unravels the affinity between customer satisfaction and loyalty. The index of fit for the current survey model is displayed in the above table, taking degrees of freedom (10) into account; most index values approach the general standard of index fit. Analysis of model demonstrates that it is critical $(\mathrm{Chi}=583.41)(\mathrm{P}<0.05)$. 
Figure 2: the result of Conceptual Model (AMOS)

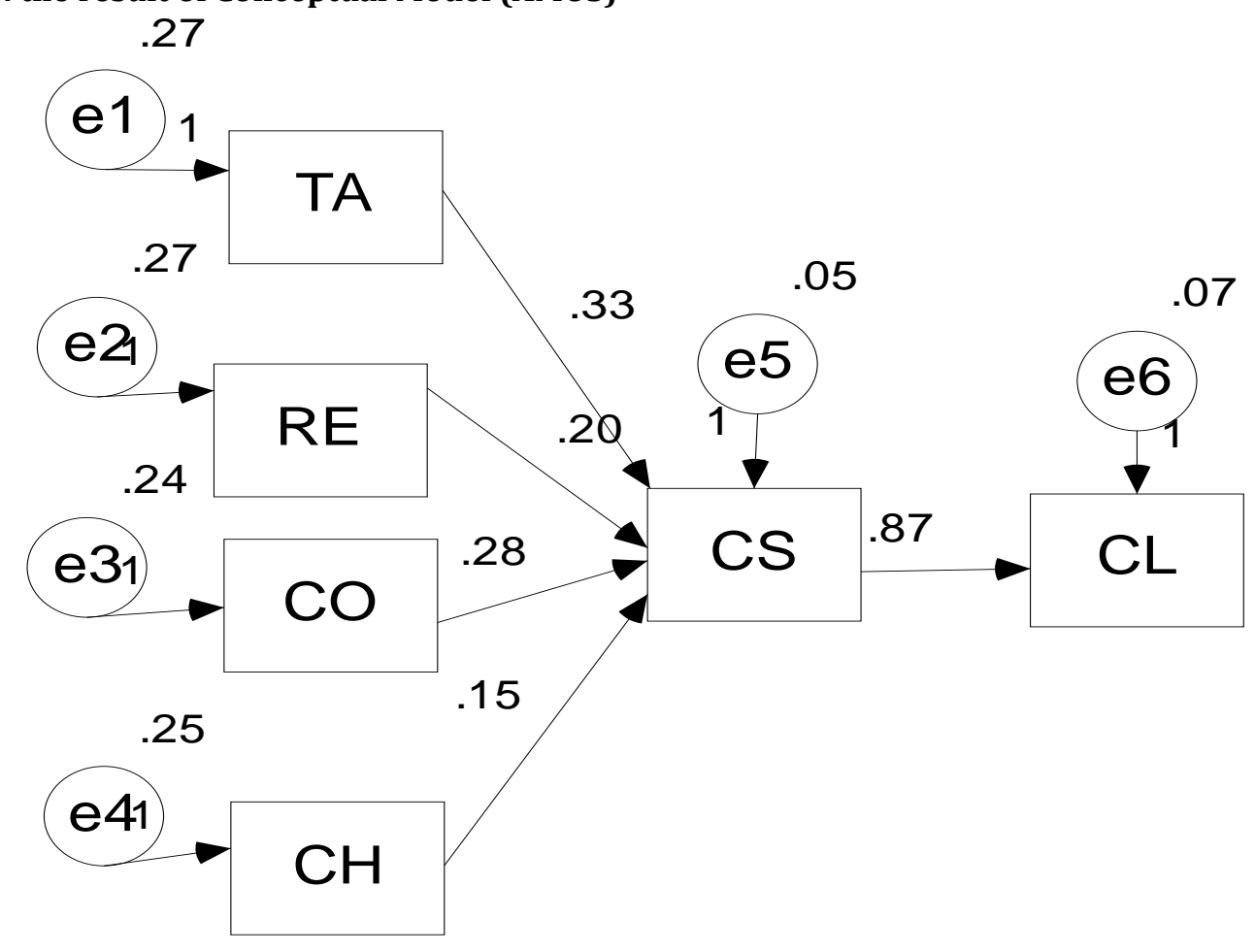

TA Tangibility

CO Competence
RE Reliability
$\mathrm{CH} \quad$ Conflict Handing

CS Customer Satisfaction CL Customer Loyalty

Table 3: Index of fit of the Model

\begin{tabular}{lll}
\hline \multicolumn{2}{l}{ Model Summary } & \\
Chi Square & Degree of freedom & P -value \\
\hline 583.41 & 10 & 0.000 \\
\hline
\end{tabular}

Table 4: Hypotheses testing based on Regression weights

\begin{tabular}{lllllll}
\hline \multicolumn{2}{l}{ Variables } & Estimates & S.E. & Critical Ratio & P-value & Results \\
\hline CS $<---$ & TA & 0.327 & .030 & 10.827 & 0.000 & Accepted \\
CS $<---$ & RE & 0.201 & .030 & 6.641 & 0.000 & Accepted \\
CS $<---$ & CO & 0.278 & .032 & 8.657 & 0.000 & Accepted \\
CS $<---$ & CH & 0.153 & .031 & 4.877 & 0.000 & Accepted \\
CL $<---$ & CS & 0.874 & .057 & 15.226 & 0.000 & Accepted \\
\hline
\end{tabular}

The Result of above hypotheses test of the affinity among variables including service quality (tangibility, reliability, competence, conflict handling), customer satisfaction and customer loyalty in Banking sector are shown in table 4 and figure two. The results of above table 4 show the regression co-efficient (Beta) value is 0.327 between tangibility (TA) and customer satisfaction (CS) and the affinity has been determined by examining that if tangibility changes by $1 \%$ there would be almost $33 \%$ change in customer satisfaction and $\mathrm{p}$-value $(\mathrm{p}<0.05)$ suggests that there is significant affinity among both of these elements. Whereas, the affinity among reliability (RE) and customer satisfaction (CS), competence (CO) and customer satisfaction, conflict 
handling $(\mathrm{CH})$ and satisfaction, the co-efficient values $0.201,0.278$ and 0.153 show the change in each variable with customer satisfaction respectively and it has been demonstrated that the affinity is statistically critical $(\mathrm{p}<0.05)$ between dependent and independent variables. The analysis highlights the relationships between customer satisfaction and customer loyalty are statistically significant $(\mathrm{P}<.05)$ and customer satisfaction contributes 87.4 percent in customer loyalty. Therefore, all the constructs merged in service quality play an important role in customer loyalty in Pakistani banking sector.

The results make it obvious that regression coefficients of tangibility, reliability, competence conflict handling are almost 0.5 and $p$ values are less than 0.05 indicates the importance of these independent constructs in customer satisfaction and coefficient value of customer satisfaction (0.874) shows the highly relationship with customer loyalty. The results of the study demonstrate that the hypotheses (H1, H2, H3, H4 and H5) are accurate and shows that tangibility, reliability, competence conflict handling have maximum affinity with customer satisfaction and customer satisfaction is has maximum affinity with customer loyalty. The results of present study are in line with previous studies such as Fen \& Lian (2007) established both customer satisfaction and service quality as predictors for re-patronage in restaurant industry moreover they found customer satisfaction as a more powerful seer of re-patronization. Bearden \& Teel (1983) suggested that customer satisfaction is critical, as it is an important seer of customer loyalty.

\section{Conclusion, Limitations and Future Research}

This study measures the effect of most common constructs for quality of banking services that influence customer satisfaction and examine the impact of customer satisfaction on customer loyalty in the context of banking relationships. It is quite evident from the results that theory and practice in different areas are closely related, for instance, the service quality constructs and customer satisfaction are very important and there is positive and significant relationship between these variables it means the change of one point of each construct of service quality effects the customer satisfaction, whereas, it is concluded that the customer satisfaction and customer loyalty have the strong positive relationship with each other and the change in one point of customer satisfaction contributes almost 87 percent in customer loyalty. With increased tangibility of the banking services the customer satisfaction is affected positively. As all the hypotheses are correct the conceptual model gets automatically correct. All the service quality constructs result in increased customer satisfaction. The satisfaction of customer in banking leads to customer Loyalty in Banking.

Limitations and Future Research: This study is based upon easy sampling processes, which prohibits general nature; a random probability sampling method can provide results that are more accurate. Due to limitations of time and budget, the study has been carried out on a small scale that could be expanded in future. In addition, there exists a significant difference in literacy level of clientele of the different banks in different cities which may be taken into account in future studies.

\section{References}

Angur, M. G., Nataraajan, R. \& Jahera, J. S. (1999). Service Quality in the banking industry: an assessment in a developing economy. International Journal of Bank Marketing, 17(3), 116-123.

Bearden, W. O. \& Teel, J .E. (1983). Selected Determinants of Consumer Satisfaction and Complaint Reports. Journal of Marketing Research, 20(1), 21-28.

Berry, L. L. (1995). Relationship marketing of services-growing interest, Emerging Perspectives. Journal of the Academy of Marketing Science, 23(4), 236-245.

Bitner, M. J., Booms, B .H. \& Tetreault, M .S. (1990). The service Encounter: Diagnosing Favorable and Unfavorable Indents. Journal of Marketing, 54(1), 71-84.

Bloemer, J., de-Ruyter, K. \& Wetzels, M. (1999). Linking perceived service quality and service loyalty: A multidimensional perspective. European Journal of Marketing, 33(11/12), 1082-1106.

Bolton, R. N. (1998). A Dynamic Model of the Duration of the Customer's Relationship with a Continuous Service Provider: The Role of Satisfaction. Marketing Science, 17(1), 45-65.

Bolton, R. N. \& Drew, J.H. (1991). A Multistage Model of Customers: Assessments of Service Quality and Value. Journal of Consumer Research, 17(4), 375-385. 
Buzzell, R. D. \& Gale, B. T. (1987). The PIMS Principles: Linking Strategy to Performance, The Free Press, and New York.

Cadotte, E. R., Woodruff, R. B. \& Jenkins, R. L. (1987). Expectations and Norms in Models of Consumer Satisfaction. Journal of Marketing Research, 24 (3), 305-314.

Churchill, G. A. \& Surprenant, C. (1982). An investigation into the determinants of customer satisfaction. Journal of Marketing Research, 19(4), 491-504.

Cronin, J. J. \& Taylor, S. A. (1992). Measuring service quality: A re-examination and extension. Journal of Marketing, 56(3), 55-68.

Drucker, P. F. (2001). The new workforce. The Economist, 3, 8-12.

Dwyer, F. R., Schurr, P. H. \& Oh, S. (1987). Developing buyer-seller relationships. Journal of Marketing, 51(2), $11-27$.

Fen, Y. S. \& Lian, K. M. (2007). Service quality and customer satisfaction: Antecedents of customer's repatronage intentions. Sunway Academic Journal, 4(1), 59 - 73.

Fornell, C. (1992). A National Customer Satisfaction Barometer: The Swedish Experience. Journal of Marketing, 56(1), 6-21.

Gurau, C. (2002). Online banking in transition economies: the implementation and development of online banking systems in Romania. International Journal of Bank Marketing, 20 (6), 285-296.

Hellier, P. K., Geursen, G. M., Carr, R. A. \& Rickard, J. A. (2003). Customer repurchases intention: A general structural equation model. European Journal of Marketing, 37(11), 1762-1799.

Heskett, J. L., Jones. T., Loveman, G., Sasser, W. \& Schlesinger, L. (1994). Putting the service profit chain to work. Harvard Business Review, 72(2), 164-174.

Howcroft, B., Hamilton, R. \& Hewer P. (2002). Consumer attitude and the usage and adoption of home based banking in the United Kingdom. International Journal of Bank Marketing, 20 (3), 111-21.

Johnston, R. (1995). The Determinants of Service Quality: Satisfiers and Dissatisfies. International Journal of Service Industry Management, 6(5), 53-71.

Jun, M. \& Cai, S. (2001). The key Determinant of Internet Banking Services Quality: A content analysis. International Journal of Bank Marketing, 19(7), 276-291.

Khalifa, M. \& Liu, V. (2003). Determination of Satisfaction at Different Adoption Stages of Internet Based Services. Journal of Association for Information System, 4(5), 206-232.

Liao, Z. \& Cheung, M. T. (2002). Internet-based e-banking and consumer attitudes: An empirical study. Information \& Management, 39(4), 283-95.

Liu, C. \& Arnett, K. P. (2000). Exploring Factors Associated with Web Site Success in the Context of Electronic Commerce. Information and Management, 38(2), 23 - 33.

Mckinney, V., Yoon, K. \& Zahedi, F .M. (2002). The Measurement of Web Customer Satisfaction: An Expectation and Disconfirmation approach. Information System Research, 13(3), 296-315.

McShane, S. \& Travaglione, T. (2007). Organizational behavior on the Pacific Rim (2 ${ }^{\text {nd }}$ Ed.), Pty Ltd, New South Whales: McGraw-Hill Australia

Mefford, R. N. (1993). Improving service Quality: Learning from Manufacturing. International Journal of Production Economics, 30, 399-413.

Mishra, A. A. (2009). A study on Customer Satisfaction in Indian Retail Banking. IUP Journal of Management Research, 8(11), 45-61.

Mols, N .P. (2000). The Internet and services marketing the case of Danish retail banking Internet Research. Electronic Networking Applications and Policy, 10(1), 7-18.

Ndubisi, N., Malhotra, N. \& Wah, C. (2009). Relationship marketing, Customer satisfaction and loyalty: a Theoretical and Empirical Analysis from an Asian Perspective. Journal of International Consumer marketing, 21(1), 5-16.

Oliver, R .L. (1980). A Cognitive Model of the Antecedents and Consequences of Satisfaction decisions. Journal of marketing research, 17(4), 460-469.

Parasuraman, A. \& Grewal, D. (2000). The Impact of Technology on the Quality Value Loyalty Chain. A Research Agenda. Journal of Academy of Marketing science, 28(1), 168-174.

Parasuraman, A. (1991). Refinement and reassessment of the SERVQUAL scale. Journal of Retailing, 67(4), 420-450.

Parasuraman, A., Berry, L. L. \& Zeithaml, V. A. (1991). Understanding Customer Expectations of Service. Sloan Management Review, 32(3), 39-48. 
Parasurman, A., Zeithaml, V. A. \& Berry, L. L. (1988). SERVQUAL: A Multiple-Item Scale for Measuring Consumer Perceptions of Service Quality. Journal of Retailing, 64 (1), 12-40.

Patterson, J. B. \& Marks, C. (1992). The client as customer: Achieving service quality and customer satisfaction in rehabilitation. Journal of Rehabilitation, 58(4), 16-21.

Patterson, P. \& Spreng, R. (1997). Modeling the relationship between perceived value, satisfaction and repurchase intentions in a business-to-business, services context: An Empirical examination. International Journal of Service Industry Management, 8(5), 414-434.

Patterson, P. G., Johnson, L. W., \& Spreng, R. A. (1997). Modeling the Determinants of Customer Satisfaction for Business-to-Business Professional Service. Journal of the Academy of Marketing Science. (25(1), 4-17

Pitt, M., Bruwer, J., Nel, D. \& Berthon, P. (1999). A framework for research in internal marketing and the study of service quality: Some propositions. Management Research News, 22(7), 11-19.

Rusbult, C. E., Farrell, D., Rogers, D. \& Mainous, A. G. (1988). Impact of exchange variables on exit, voice, loyalty, and neglect: An integrative model of responses to declining job satisfaction. Academy of Management Journal, 31(3), 599-627.

Rust, R. \& Zahorik, A. J. (1993). Customer Satisfaction, Customer Retention, and Market Share. Journal of Retailing, 69(2), 193-215.

Spreng, R. A., Mackenzie, S. B. \& Olshavky, R. W. (1996). A Re-examination of the Determinants of Customer Satisfaction. Journal of Marketing, 60(3), 15-33.

Stank, T., Goldsby, T. \& Vickery, S. (1999). Effect of Service Supplier Performance on Satisfaction and Loyalty of Store Managers in the Fast Food Industry. Journal of Operations Management, 17(2), 429 447.

Swan, J. E. \& Trawick, I. F. (1981). Disconfirmation of Expectations and Satisfaction with a Retail Service. Journal of Retailing, 57(3), 49-67.

Taylor, S. A. \& Baker, T. L. (1994). An Assessment of the Relationship between Service Quality and Customer Satisfaction in the Formation of Consumers' Purchase Intentions. Journal of Retailing, 70(2), 163 $-178$.

Yang, Z. \& Fang, X. (2004). Online Service Quality Dimensions and their Relationships with Satisfaction: A Content Analysis of Customer Reviews of Securities Brokerage Services. International Journal of Service Industry Management, 15(3), 302-326.

Yavas, U., Bigin, Z. \& Shenwell, D. (1997). Service quality in the banking sector in an emerging economy: A consumer survey. International Journal of Banking Marketing, 15 (6), 217-223.

Zeithaml, V. A. (1988). Consumer perceptions of price, quality, and value: A means-end model and synthesis of evidence. Journal of Marketing, 52(3), 2 - 22.

Zeithaml, V. A. Parasuraman, A. \& Malhotra, A. (2002). Service Quality Delivery through Web sites: A Critical Review of Extent knowledge. Journal of the Academy of Marketing Science, 30(4), 362-375.

Zeithaml, V. A., Berry, L. L. \& Parasuraman, A. (1996). The behavioral consequences of service quality. Journal of Marketing, 60(2), 31-46.

Zeithaml, V. A., Parasuraman, A. \& Berry L. L. (1990). Delivering quality service: balancing customer perceptions and expectations, The Free Press: New York. 